\title{
Elderly and Patient Care Education; Social Support Program (SODES) Project of Turkish Republic Ministry of Development
}

\author{
Yaşlı ve Hasta Bakım Eğitimi; Türkiye Cumhuriyeti Kalkınma Bakanlığı Sosyal Destekleme Programı (SODES) \\ Projesi
}

\author{
Nilgun ULUTASDEMIR ${ }^{1}$
}

\begin{abstract}
The aim of the study is to evaluate the theoretical and practical training given to the unemployed women who are disadvantaged group for the health care of the elder people who are also disadvantaged group, within the scope of the project. Hundred participants registered in the Social Support Program (SODES) Project of Turkish Republic Ministry of Development. Proje name is "My elderly and my patient are in safe hands with SODES" in cooperation with Social Assistance Foundation of Sahinbey Gaziantep Governorship's Office in 2013-2014. Surveys related to demographic features, elderly care applications and first aid were applied to participants before and after trainings. Wilcoxon, Mann Whitney U, Kruskal Wallis tests and Spearman Correlation Analysis were used. $\mathrm{p}<0,05$ was accepted as statistical significance. The $100,0 \%$ of the elderly care providers were unemployed women, the mean age of participants was $33,29 \pm 10,66,38,0 \%$ of them were graduated from primary school, and $8,0 \%$ of them had graduate degree. Besides, $57 \%$ of them were married, $60 \%$ of them had child/children, $44,0 \%$ of them had elderly relatives, and $19,0 \%$ of them had an eldercare experience. Mean knowledge scores after trainings $(72,82 \pm 7,98)$ were higher compared to scores before trainings $(35,30 \pm 17,08)(\mathrm{p}<0,05)$. There was a positive significant relationship between the eldercare pre-test and post-test scores $(r=0,790, p=0,001)$. Conclusively, it was detected that knowledge of all elderly care providers, who were included in the "My elderly and my patient are in safe hands with SODES" project, increased in the end of elderly care and first aid trainings.
\end{abstract}

Keywords: Elderly, Patient care, Patient education, SODES

\section{ÖZ}

Çalışmanın amacı, dezavantajlı grup olan işsiz kadınların, aynı zamanda dezavantajlı grup olan yaşlılara sağlık hizmetleri için verilen teorik ve pratik eğitimleri proje kapsamında değerlendirmektir. 20132014 yıllarında Şahinbey Gaziantep Valiliği Sosyal Yardım Vakfı işbirliğiyle "Yaşlım ve hastam SODES ile emin ellerde" Türkiye Cumhuriyeti Kalkınma Bakanlığı Sosyal Destek Programı (SODES) Projesine 100 katılımcı kayıt oldu. Eğitim öncesi ve sonrasında katılımcılara demografik özellikler, yaşlı bakımı ve uygulamaları, ilk yardım ile ilgili anket uygulandı. Verilerin analizinde Wilcoxon, Mann Whitney U, Kruskal Wallis testleri ve Spearman Korelasyon Analizi kullanıldı. $\mathrm{p}<0.05$ istatistiksel anlamlılık olarak kabul edildi. Yaşlı bakım sağlayıcılarının $\% 100,0$ ' 1 işsiz kadın, yaş ortalaması $33,29 \pm 10,66$, $\% 38,0^{\prime} 1$ ilkokul mezunu ve \% 8,0'1 yüksek lisans derecesine sahipti. Ayrıca \%57'si evli, \%60'ı çocuklu, $\% 44,0 ' 1$ yaşlı akrabası vardı ve \%19,0'ı yaşlı bakımı deneyimi yaşamıştı. Eğitimlerden sonra ortalama bilgi puanları $(72,82 \pm 7,98)$ eğitim öncesi puanlara göre $(35,30 \pm 17,08)$ daha yüksekti $(\mathrm{p}<0,05)$. Yaşlı bakımı ön test ve son test puanları arasında pozitif anlamlı bir ilişki vardı $(r=0,790, p=0,001)$. Sonuç olarak, "Yaşlım ve hastam SODES ile emin ellerde" projesine dahil olan tüm yaşlı bakım sağlayıcılarının bilgilerinin yaşlı bakımı ve ilk yardım eğitimleri sonunda arttığı tespit edildi.

Anahtar Kelimeler: Yaşl1, Hasta bakımı, Hasta eğitimi, SODES

This study is derived from the project "My Elderly and My Patient are in Safe Hands with SODES”. The study was presented as an oral presentation in "World Conference on Educational Sciences" which was held in Madrid Spain.

${ }^{1}$ Assoc. Prof. Dr., Nilgun ULUTASDEMIR, Public Health, Gümüşhane University, Faculty of Health Sciences, Department of Health Management, nulutasdemir@yahoo.com, ORCID: 0000-0002-2231-5236

İletişim / Corresponding Author:

Nilgun ULUTASDEMIR

e-posta/e-mail: nulutasdemir@yahoo.com

Geliş Tarihi / Received: 27.05.2021

Kabul Tarihi/Accepted: 06.09.2021 


\section{INTRODUCTION}

Among the disadvantaged groups; there are elder people, women, children, youth, disabled, refugees, unemployed, poors, foreign nationals who have the right to sit legally in other countries, etc. Disadvantaged groups are fragile, encountered with risks and they should be supported. Home health care service helps elder people who are the disadvantaged group, ensures the highest level of health, comfort and improves problematic situations. Eldercare is generally given by family members or uneducated, underserved persons, and informally. Elderly population increases throughout the world, including Turkey. There was a significant reduction in the fertility rate since the policies encouraging fertility which were pursued immediately after the proclamation of the Republic were abandoned. The reduction in the fertility rate particularly gained momentum in 1970s. Scientific and technological advances in medicine have prevented diseases and provided opportunities for the early diagnosis and the treatment. Furthermore, the rate of infant mortality has been decreased due to developments in health care services and thus the life expectancy has increased. Therefore, the rate of elderly population (65 years old and older ages) has increased.

According to population projections, it is estimated that the rate of elderly population in Turkey will increase up to 10,2\% in 2023 and Turkey will be among countries with 'very aged' population. The rate of elderly population was 7,7\% in 2013 and $8 \%$ in 2014 whereas population projections estimates that it will increased up to $10,2 \%$ in $2023,20,8 \%$ in $2050,27,7 \%$ in 2075. ${ }^{1}$ The first three United Nations, Economic Commission for Europe (UNECE) countries which had the oldest population in 2012 were respectively Italy (21\%), Germany (19,9\%) and Greece (20,7\%). Turkey was the $46^{\text {th }}$ country according to this elderly population ranking which was reported in 2012. In Population and Housing Survey (2011), families composed of only old people were evaluated and consequently there was only one old member in $60 \%$ of the families, $39,5 \%$ of the families had two old members and $0,5 \%$ of them were composed of three old member. ${ }^{2}$ Satisfaction of older individuals with their own health status was $6,7 \%$ in 2013 whereas this rate decreased $(5,8 \%)$ in $2014 .^{1,2}$ The occupancy rate of Rehabilitation Centers under the auspices of General Directorate of Disabled and Elderly Services was $92,5 \%$ in 2013 whereas it increased to $94 \%$ in $2014 .{ }^{1,2}$ In 2013, when the SODES project was performed, the rates of elderly population (per total population) in Gaziantep province were $4,8 \%$ in 2013 and $4,9 \%$ in $2014 .{ }^{1,2}$ According to the results of the "Elderly Statistics" study of Turk1sh Statistical Institue (Known as TUIK in Turkey) 2019; The population aged 65 and over, which was 6 million 192 thousand 962 people in 2014 , increased by $21,9 \%$ in the last 5 years, and reached 7 million 550 thousand 727 people in $2019 .^{3}$

The issue of aging has primarily medical and social nature. One of the main problems of gerontology is how to distinguish the changes driven by aging from the changes due to the disease. In order to cope with difficulties related to aging, more importance should be given to the preventive medicine. ${ }^{4}$ Three main points should be well understood in order to understand the aging process and make preliminary estimations. These are biological, psychological and social processes ${ }^{5,6}$ Main factors of healthy aging are education, support because of being married and being a woman. ${ }^{6,7}$ Being in a close relationship with others protect an individual from stress and family and social support delays the probability of elderly death which can happen due to various health problems. $^{8}$ People become progressively more dependent on others as they age. Therefore, daily requirements of old people are met by their family, friends or neighbors. ${ }^{9}$ However, when 'continuous health care' is needed, eldercare becomes a comprehensive 
service which requires special knowledge and unique approach. ${ }^{10}$

Elderly home care services aim to ensure old people to live independently at home and increase their life quality. ${ }^{11}$ While planning health care services at home, it should be considered that health and maximum comfort of old people should be ensured and problems should be fixed. ${ }^{12}$ In today's world, many factors including the increased life span, necessity of medical assistance, outpatient surgeries and shortened time of care at hospitals have increased the importance of home-care of patients. ${ }^{13-15}$

Home health care services are carried out in various countries such as USA, Canada, UK, Germany, France, Netherlands, Swedish, Austria, Belgium, Luxembourg, Spain, Portugal, Denmark, Ireland, Italy, Greece, Japan, Saudi Arabia, Indonesia and Taiwan. ${ }^{16}$ The Dutch home-care system is embedded in a universalistic and comparatively generous long-term care scheme that was introduced in the late 1960s. ${ }^{17}$ Accoording to Szebehely and Trydegård (2012), Swedish home care, as a universal welfare service, is now under threat and may become increasingly dominated by groups with less education and lower income which, in turn, could jeopardise the quality of care. ${ }^{18}$ As in the case of Austria limit the development of home care, particularly in countries with a traditionally strong family orientation towards long-term care. Additionally, a tradition of family care and an emphasis on cash benefits may be conducive to the employment of migrant carers in private households, as a potential substitute for both family care and formal care. $^{19}$

In Turkey, the interest in home care services is also gradually increasing. In this regard, legal regulations, which are mentioned above, are prepared as well as both academic and various organizations prepare events and educational programs and develop projects intended for home health care services. There are increasing numbers of home care arrangements which are organized by Ministry of Health as well as activities related to this topic prepared by the private sector. ${ }^{20}$ It is important to know who are responsible for meeting the requirements of old people in order to plan the health care services. ${ }^{4}$ Eldercare is becoming an important concept and increasing numbers of elder care professionals are trained and it has become a profession. $^{21}$ Increase in the elderly population requires the establishment of organizations and institutions which can provide both social and medical support. However, these kinds of organizations which can support old patients in addition to their families have not yet been common in our country. In Turkey, limited economic resources prevent us to develop specific policies related to elderly health care which is currently tried to be solved by families. Therefore, eldercare is performed by family members or uneducated, underserved and informal individuals. Studies show that health care providers are faced with various health risks due to their work, they are very sensitive and they should be supported in order to continue providing a good quality health care to old people. ${ }^{21,22}$

Working at someone's house can require cleaning, cooking, performing chores and taking care of either children or old people. ${ }^{23}$ In other words, domestic services are composed of wide range of activities such as cleaning, cooking, caring children, elderly, patient and disabled individuals. ${ }^{24}$ Domestic services are given by individuals of every age and gender whereas it is widely accepted that these kinds of services are under the responsibility of women. ${ }^{25}$ In Turkey, women migrants are employed in domestic services and they are generally living day and night at home in order to provide the elderly or patient health care service. Since Turkish people generally do not accept to live in someone's house, women migrants are frequently preferred. ${ }^{24}$ Working in a foreign home causes the uncertainty of working hours as well as eliminates the distinction of working place and home. ${ }^{26}$ Domestic services were assessed in Family Law until the $20^{\text {th }}$ century but afterwards it started to be involved in the Law of Business in various countries. ${ }^{27}$ Supreme Court ruled in 2008 that 
the work of nurses who provide patient health care, individuals who give domestic services and the work of guards are involved in the Law of Business. Because of difficulties encountered in case of home services, 'Workers Convention in Home Services' (with the number of 189) was accepted in $100^{\text {th }}$ International Labor Office (ILO) conference which was held in 2011 and important provisions were determined intended for social protection. ${ }^{25}$

It is important to be involved in training process for individuals and societies. It is obvious that societies with educated people develop faster compared to uneducated societies. Education plays an important role in both the economic and social prosperity of countries. However, it is observed that there is a difference between the male and female population in terms of participation in education. When the educational levels of older people are examined, it is found that $84 \%$ of women are not educated or did not even complete primary school education. This rate is $70 \%$ for men. The rate of older women who had high school or higher education is $2 \%$. On the other hand, $4 \%$ of older men were graduated from high school or they had higher level of education. Both educational levels and advantages of receiving education are higher for old men compared to old women. The gender difference in terms of educational opportunities is prominent in underdeveloped and developing countries. ${ }^{28}$ In Turkey, eldercare, which is currently provided by family members, will become an important profession in the future due to the urbanization and the aging of the population. Elder health care providers have, in general, started to this job due to economic reasons. They develop their skills through learning by doing. Anyhow, they need to provide a comprehensive care that should include all dimensions from biological, social and physiological aspects. Elderly health care is a type of service that can even be given by uneducated people provided that the establishment of empathy and which can be provided at home and not necessarily at nursing home. Elderly health care is a new occupation and difficulties can be decreased if supported by education. This demand which emerged spontaneously should be noticed by authorities, individuals who provide elderly health care should be encouraged, their requirements should be met and psychological and educational supports should be provided to them in order to ensure that they are healthy. ${ }^{9}$

The prerequisite of being a good quality and effective eldercare can be that health care providers should be an expert and they should be devoted to this profession. Therefore, elderly care providers should be selected according to these principles and they should be educated and supported in terms of material and spiritual aspects. ${ }^{29}$ Women who work in child, patient and elderly care need education about pedagogy, nutrition, hygiene and health issues. Besides, women who work in cleaning jobs should be educated about general hygiene rules, and material and machine utilization. In this regard, institutions of vocational qualifications and Turkish Employment Agency (Known as İŞKUR in Turkey) should undertake the task. There were 5278 individuals who attended to the child care, disability care, patient and elderly care courses in 2012 and 4626 of them were women and only 662 of them were men. It is also important for an employee to find an honest and loyal individual since the point is to entrust the home, child or old relative to another person. ${ }^{30}$ Recently, elder people need the state support as well as professional services. The state policy in Turkey claims that elderly care will be more effective in case old people receive health care at home and in their social environment by family members or professional health care providers instead of receiving health care in institutions. ${ }^{31}$

In Turkey, it is obvious that there will be higher demand for elderly care in the future due to an increasing number of old people. Throughout the world as well as in Turkey, elderly health care services will become an occupational and a new business area. It is important to solve problems 
intended for the elderly care and assess the eldercare education in terms of its reflections to the quality of the health care. For the health care services of unemployed women and the elderly, who are disadvantaged groups, universities should establish standards and qualifications, opportunities should also be provided by the private sector and there should be competition in terms of the elderly health care. The aim of the study is to evaluate the theoretical and practical training given to the unemployed women who are disadvantaged groups for the health care of the elderly, who are also disadvantaged groups, within the scope of the project.

\section{MATERIAL VE METHOD}

\section{Study Design and Population}

The study group was composed of participants who were registered in "My elderly and my patient are in safe hands with SODES" project that was conducted by Gaziantep Social Assistance and Solidarity Association of Sahinbey Governor's Office in collaboration between 25 May 2013 and 25 May 2014. Within the scope of the SODES project, the people who will be given health education and the people who will apply the education they received were selected from among the disadvantaged groups. The criteria for selecting 100 participants in the project were as follows: to reside in the Sahinbey District in Gaziantep, to have at least a primary school degree, and to be unemployed and women from disadvantaged groups. The subject and content of the training provided in the project was elderly care. And the people to whom this training will be implemented were chosen as elder people from disadvantaged groups.

\section{Data Collection}

Data of the study were collected by using the survey which contained demographic features of participants or by applying the survey which contained questions about elderly care before and after trainings.

\section{Data Analysis}

In order to performed statistical analyses, Wilcoxon signed rank test, Mann-Whitney U test, Kruskal-Wallis test, Spearman Correlation tests were used since our data were not normally distributed. Statistical significance was accepted when $\mathrm{p}$ values was lower than $0,05(\mathrm{p}<0,05)$.

\section{Ethical Aspect of Research}

Permissions were obtained both from SODES Unit of Gaziantep Governor and University Human Research Ethics Committee (01.12.2014, No: 33) in Social Sciences.

\section{Providing Elderly Care Education}

Theoretical and practical elderly health care trainings were given by 2 instructors during 10 hours. Trainings were given to two groups (composed of 50 individuals in each) during 2 days. During the training, lectures were given as well as question and answer, role-play, demonstration methods were also used in order to ensure the active participation of elderly care providers. The training program was composed of elderly care applications such as home care, inpatient care, bedridden patient care, body care, oral and dental care, hand washing, communication, nutrition of the elderly, the elderly mobilization, simple medical applications, medical applications, bedsore care, body systems and its diseases, elderly anatomy, diseases in old people, drug use in old age, pain in old age, exercise, social and psychological aspects of aging, aging indicators, nutrition, dressing, bathing in the elderly, mental health problems in old age, roles of family members in elderly care, providing safe environment to old people, responsibilities of care givers and first aid topics envisaged by the Ministry of Health. Trainings were given to participants by giving slide lectures as well as giving the 
opportunity to perform applications on models. Training period was finalized after participants were given a elderly in one of the private hospitals located in Gaziantep province in order to apply techniques that they learned during trainings. The data of the study were collected by using information inquiry which was composed of 5 questions regarding the socio-demographic features of participants. Additionally, elderly health care survey, which was composed of 55 questions, was also used for the data collection. The elderly health care survey was composed of questions related to topics such as arranging the room of elderly and old people, performing body care and hygiene, wound care, follow-up of liquid that the elderly drinks in 24 hours and total amount of liquid that the elderly removes from the body (urine) in 24 hours, bedsore care, chronic patient care, nutrition, exercise, sleeping, resting, drug use, psychological support, communication, health training and first aid. This survey was applied to participants before and after trainings upon explaining the concept of the survey. Elderly care providers, who were successful in both theoretical and practical elderly health care trainings, received the 'Elderly Health Care Provider Certificate'. Totally 34 elderly care providers were employed in private and public institutions located in Gaziantep province.

\section{RESULTS AND DISCUSSION}

The $100,0 \%$ of the participants were unemployed women. The mean age of participants was 33,29 $\pm 10,66$ (Min: 18, Max:55). Besides, $38 \%$ of them were graduated from primary school, $8,0 \%$ of them graduated from university. Of all elderly care providers, $57 \%$ of them were married and $60 \%$ of them had child/children. Sociodemographic characteristics of elderly health care providers can be seen in Table 1 . Single, under 30 and college students' eldercare and first aid the pre-test and posttest results are higher $(\mathrm{p}<0,05)$ (Table 1).

Table 1. Mean Scores of Elderly Patient Care Education Knowledge Levels of Elderly Care Providers According To Their Sociodemographic Features

\begin{tabular}{|c|c|c|c|c|c|c|}
\hline \multicolumn{2}{|c|}{ Demographic Variables } & \multirow{2}{*}{$\begin{array}{l}\mathbf{N}(\%) \\
88(\% 88,0)\end{array}$} & \multirow{2}{*}{$\begin{array}{l}\begin{array}{l}\text { Pre-Test } \\
(\text { Mean } \pm \text { SD })\end{array} \\
31,66 \pm 16,83\end{array}$} & \multirow{2}{*}{$\begin{array}{l}\text { Pre-Test } \\
\text { p, U, Kw-h } \\
U=-1,010 \\
p=0,313\end{array}$} & \multirow{2}{*}{$\begin{array}{l}\text { Post-Test } \\
(\text { Mean } \pm \text { SD) }\end{array}$} & \multirow{2}{*}{$\begin{array}{l}\begin{array}{l}\text { Post-Test } \\
\text { p, U, Kw-h }\end{array} \\
U=-0,954 \\
p=0,340\end{array}$} \\
\hline & Male & & & & & \\
\hline \multirow[t]{2}{*}{ Gender } & Female & $12(\% 12,0)$ & $35,79 \pm 17,15$ & & $73,05 \pm 8,04$ & \\
\hline & 30 age and under & $41(\% 41)$ & $41,78 \pm 16,99$ & & $75,43 \pm 8,70$ & \\
\hline \multirow[t]{3}{*}{ Age } & $31-45$ age & $47(\% 47)$ & $31,54 \pm 15,60$ & $\begin{array}{l}\text { Kw-h=5,649 } \\
p=0,005\end{array}$ & $71,27 \pm 6,72$ & $\begin{array}{l}\mathrm{Kw}-\mathrm{h}=4,081 \\
\mathrm{p}=0,020\end{array}$ \\
\hline & 46 and above & $12(\% 12)$ & $28,60 \pm 16,62$ & & $70,20 \pm 7,7$ & \\
\hline & Single & $57(\% 57)$ & $43,35 \pm 19,52$ & & $76,62 \pm 9,3$ & \\
\hline \multirow[t]{3}{*}{$\begin{array}{l}\text { Marital } \\
\text { status }\end{array}$} & $\begin{array}{l}\text { Widow/Divorced/Separate } \\
\text { d }\end{array}$ & $40(\% 40)$ & $37,33 \pm 4,04$ & $\begin{array}{l}\mathrm{Kw}-\mathrm{h}=8,927 \\
\mathrm{p}=0,001\end{array}$ & $72,33 \pm 4,0$ & $\begin{array}{l}\text { Kw-h=8,906 } \\
p=0,001\end{array}$ \\
\hline & Married & $3(\% 3)$ & $29,54 \pm 13,03$ & & $70,17 \pm 5,81$ & \\
\hline & $\begin{array}{l}\text { Graduated from primary } \\
\text { school }\end{array}$ & $38(\% 38)$ & $23,76 \pm 8,54$ & & $68,02 \pm 3,70$ & \\
\hline \multirow[t]{4}{*}{$\begin{array}{l}\text { Educational } \\
\text { status }\end{array}$} & $\begin{array}{l}\text { Graduated from secondary } \\
\text { school }\end{array}$ & $15(\% 15)$ & $32,20 \pm 6,89$ & & $71,06 \pm 4,25$ & \\
\hline & $\begin{array}{l}\text { Graduated from } \\
\text { high school }\end{array}$ & $35(\% 35)$ & $35.42 \pm 9,41$ & $\begin{array}{l}\mathrm{Kw}-\mathrm{h}=74,599 \\
\mathrm{p}=0,001\end{array}$ & $72,51 \pm 4,65$ & $\begin{array}{l}K w-h=57,209 \\
p=0,001\end{array}$ \\
\hline & Having an associate degree & $4(\% 4)$ & $65,16 \pm 7,54$ & & $85,00 \pm 7,18$ & \\
\hline & College student & $8(\% 8)$ & $73,00 \pm 8,40$ & & $91,00 \pm 4,47$ & \\
\hline
\end{tabular}

$\mathrm{SD}=$ Standard Deviation, U=Mann Whitney U test, , Kw-h=Kruskall Wallis-h testi 
It was shown that $41 \%$ of the elderly care in their families and $44 \%$ of them were The distribution of the pre-test and post-test health care can be seen in Table 2. According gave the best answers to questions related to nutrition, arrangement of the patient room the best answers were given about the resting and body care after trainings. There between the pre-test and post-test scores in content of trainings $(\mathrm{p}<0,05)$ (Table 2$)$. providers specified that they had old relatives already experienced in the elderly health care. answers of participants related to the elderly to the evaluation of answers, participants the communication, psychological support, and wound care before trainings. However, arrangement of the patient room, sleeping, was a statistically significant difference each of the 15 topics which constituted the

Table 2. Distribution of True Answers of Elderly Care Providers Which Were Given According to Pre-Test and Post-Test Questions

\begin{tabular}{|c|c|c|c|c|}
\hline Ouestions & $\begin{array}{l}\text { Pre-Test } \\
\text { N } \%\end{array}$ & $\begin{array}{l}\text { Pre-Test } \\
\text { p, U Value }\end{array}$ & $\begin{array}{l}\text { Post-Test } \\
\text { N \% }\end{array}$ & $\begin{array}{l}\text { Post-Test } \\
\text { p, U Value }\end{array}$ \\
\hline Arrangement of the patient room & $26(\% 26)$ & $\begin{array}{l}\mathrm{U}=-5,070 \\
\mathrm{p}=0,001\end{array}$ & $100(\% 100)$ & $\begin{array}{l}\mathrm{U}=-4,515 \\
\mathrm{p}=0.001\end{array}$ \\
\hline $\begin{array}{l}\text { Fever, pulse, respiration and blood pressure } \\
\text { assessment (FPRBA) }\end{array}$ & $3(\% 3)$ & $\begin{array}{l}\mathrm{U}=-2,507 \\
\mathrm{p}=0,012\end{array}$ & $51(\% 51)$ & $\begin{array}{l}\mathrm{U}=-2,076 \\
\mathrm{p}=0,038\end{array}$ \\
\hline $\begin{array}{l}\text { Follow-upliquids that the patient drinks and } \\
\text { removes from the body }\end{array}$ & $3(\% 3)$ & $\begin{array}{l}\mathrm{U}=-2,855 \\
\mathrm{p}=0,004\end{array}$ & $40(\% 40)$ & $\begin{array}{l}\mathrm{U}=-2,851 \\
\mathrm{p}=0,004\end{array}$ \\
\hline Wound Care & $22(\% 22)$ & $\begin{array}{l}\mathrm{U}=-4,841 \\
\mathrm{p}=0,001\end{array}$ & $55(\% 55)$ & $\begin{array}{l}U=-3,773 \\
p=0,001\end{array}$ \\
\hline Bedsore Care & $13(\% 13)$ & $\begin{array}{l}\mathrm{U}=-5,330 \\
\mathrm{p}=0,001\end{array}$ & $92(\% 92)$ & $\begin{array}{l}U=-5,244 \\
p=0,001\end{array}$ \\
\hline Chronic Patient Care & $1(\% 1)$ & $\begin{array}{l}\mathrm{U}=-1,561 \\
\mathrm{p}=0,118\end{array}$ & $84(\% 84)$ & $\begin{array}{l}U=-1,629 \\
p=0,103\end{array}$ \\
\hline Exercise & $17(\% 17)$ & $\begin{array}{l}\mathrm{U}=-5,386 \\
\mathrm{p}=0,001\end{array}$ & $93(\% 93)$ & $\begin{array}{l}\mathrm{U}=-4,845 \\
\mathrm{p}=0,001\end{array}$ \\
\hline Sleeping & $19(\% 19)$ & $\begin{array}{l}\mathrm{U}=-2,941 \\
\mathrm{p}=0,003\end{array}$ & $100(\% 100)$ & $\begin{array}{l}U=-2,084 \\
p=0,037\end{array}$ \\
\hline Resting & $17(\% 17)$ & $\begin{array}{l}\mathrm{U}=-4,932 \\
\mathrm{p}=0,001\end{array}$ & $100(\% 100)$ & $\begin{array}{l}U=-2,065 \\
p=0,008\end{array}$ \\
\hline Drug Use & $15(\% 15)$ & $\begin{array}{l}U=-5,763 \\
p=0,001\end{array}$ & $55(\% 55)$ & $\begin{array}{l}U=-5,363 \\
p=0,001\end{array}$ \\
\hline Body Care & $10(\% 10)$ & $\begin{array}{l}U=-3,840 \\
p=0,001\end{array}$ & $99(\% 99)$ & $\begin{array}{l}U=-2,290 \\
p=0,022\end{array}$ \\
\hline Nutrition & $23(\% 23)$ & $\begin{array}{l}\mathrm{U}=-5,284 \\
\mathrm{p}=0,001\end{array}$ & $57(\% 57)$ & $\begin{array}{l}U=-5,757 \\
p=0,001\end{array}$ \\
\hline Psychological support & $23(\% 23)$ & $\begin{array}{l}\mathrm{U}=-3,944 \\
\mathrm{p}=0,001\end{array}$ & $99(\% 99)$ & $\begin{array}{l}\mathrm{U}=-2,625 \\
\mathrm{p}=0,009\end{array}$ \\
\hline Communication & $29(\% 29)$ & $\begin{array}{l}\mathrm{U}=-6,151 \\
\mathrm{p}=0,001\end{array}$ & $86(\% 86)$ & $\begin{array}{l}U=-3,957 \\
p=0,001\end{array}$ \\
\hline Health Training & $8(\% 8)$ & $\begin{array}{l}\mathrm{U}=-4,607 \\
\mathrm{p}=0,001\end{array}$ & $62(\% 62)$ & $\begin{array}{l}U=-4,650 \\
p=0,001\end{array}$ \\
\hline
\end{tabular}

$\mathrm{U}=$ Mann Whitney U test

The mean score distribution of elderly health before and after the trainings can be seen in scores of participants $(35,30 \pm 17,08)$ compared to $(72,82 \pm 7,98)$ was statistically significant care knowledge levels of participants Table 3. The increase in the mean pre-test the mean post-test scores of participants $(\mathrm{p}<0.05)$ (Table 3). 
Table 3. Distribution of Mean Scores of Elderly Patient Care Education Knowledge Levels of Elderly Care Providers Before and After the Training

\begin{tabular}{lccccc}
\hline $\begin{array}{l}\text { Mean scores of elderly patient care education } \\
\text { knowledge levels }\end{array}$ & N & Min & Max & Mean \pm SD & p \\
\hline Pre-Test & 100 & 14 & 84 & $35,30 \pm 17,08$ & 0,001 \\
\hline Post-Test & 100 & 65 & 98 & $72,82 \pm 7,98$ \\
\hline
\end{tabular}

$\mathrm{SD}=$ Standard Deviation

The distribution of mean first aid knowledge trainings can be seen in Table 4. It was found of participants before trainings $(80,15 \pm 11,13)$ scores obtained after trainings $(28,20 \pm 15,61)$ scores of participants before and after the that mean first aid knowledge level scores were statistically higher compared to mean $(\mathrm{p}<0.05)$ (Table 4)

Table 4. Distribution of Mean Scores of First Aid Knowledge Levels of Elderly Care Providers Before and After The Training

\begin{tabular}{llllll}
\hline Mean scores of first aid knowledge levels & N & Min & Max & Mean \pm SD & p \\
\hline Pre-Test & 100 & 12.5 & 70 & $28,20 \pm 15,610$ & 0.01 \\
\hline Post-Test & 100 & 65 & 97.5 & $80,15 \pm 11,13$ & \\
\hline
\end{tabular}

$\mathrm{SD}=$ Standard Deviation

The distribution of the mean elderly care after trainings can be seen in Table 5. It was association between the pre-test and post-test participants $\quad(\mathrm{r}=0,790, \quad \mathrm{p}=0,001)$. The knowledge scores of participants before and found that there was a strong and positive test mean first aid knowledge scores of knowledge scores of participants before and detected that there was a strong and positive mean elderly care knowledge scores of correlation between mean first aid after trainings can be seen in Table 5. It was association between the pre-test and postparticipants $(\mathrm{r}=0,873, \mathrm{p}=0,01)$ (Table 5).

Table 5. Correlation Between Mean Scores of Elderly Patient Care and First Aid Knowledge Levels of Elderly Care Providers Before and After The Training

\begin{tabular}{lcc}
\hline & \multicolumn{2}{c}{$\begin{array}{l}\text { Mean scores of elderly patient care and first aid knowledge } \\
\text { levels of elderly care providers before and after the training }\end{array}$} \\
\cline { 2 - 3 } & $\mathbf{r}$ & $\mathbf{p}$ \\
\hline $\begin{array}{l}\text { Mean scores of elderly patient care education } \\
\text { knowledge levels before the training }\end{array}$ & 0,790 & 0,001 \\
$\begin{array}{l}\text { Mean scores of first aid knowledge levels before } \\
\text { the training }\end{array}$ & 0,873 & 0,01 \\
\hline
\end{tabular}

$\mathrm{r}=$ Spearman Korelasyon

Providing elderly health care by family members, who are not trained in this regard, can lead to complications. By considering these complications, home care applications should be developed, health care providers should be supported and trained. ${ }^{32}$ BergWeger and Tebb (2003-2004) emphasized that there should be interventions based on the evidences and studies related to these applications performed by researchers and 
practitioners in order to provide service to health care providers. They also stated that these kinds of studies can affect the planning of programs and policies related to eldercare. ${ }^{33}$ In Turkey, there are various publications related to the features and problems of eldercare providers such as family members, relatives and elderly. However, there is no such study which can assess the profile, professional perspective, choices and the effectiveness of the education of the health care providers. There are differences between studies which have been performed on the effectiveness of the elderly care training since different methods and scales were used. Therefore, the comparison of our findings with results of other studies is limited..$^{32-37}$

In the context of "My elderly and my patient are in safe hands with SODES" project, $100,0 \%$ of participants were unemployed women. Similarly, according to the results of studies performed by Dramal1, Demir, and Yavuz (1998) and Altun (1998) respectively $89,9 \%$ and $78,0 \%$ of the elderly health care providers were also women. ${ }^{38,39}$ It may be caused by economic challenges due to the lack of a well paid job.

In Turkey, majority of professional elderly care providers working at home are graduated from primary school or they have even the lower level of education. ${ }^{10}$ The higher recruitment criteria are important in this regard. In this project, $41 \%$ of the elderly care providers specified that they had older people in their families. Similarly, there are studies which indicated that health care providers had also old family members. ${ }^{32,38,39}$ Individuals may want to continue living in an environment where they got used to live and relaxed. Of all elderly care providers, $86 \%$ of them specified that they were not trained about elderly care and they also stated that they needed education and support in this regard. Our results are similar to findings of other studies in the literature. ${ }^{38,39}$ It is very important that participants want to receive education about elderly health care and it is a positive conclusion since the importance of the education comes into a question.

Eldercare mean knowledge scores of participants before trainings were $35,30 \pm 17,08$ whereas mean scores increased up to $72,82 \pm 7,98$ after trainings. Similarly, In Aslam Arain, Graham, Ahmad and Cole's study the majority of participants reported an increase in their knowledge about caring for elderly patients. ${ }^{40}$ Cingil, Gozum and Bodur (2015) performed a study by using elderly care knowledge evaluation test and they found significant difference between the control and experimental groups in terms of their pre-test and post-test scores. ${ }^{32}$ Temizer and Gozum (2012) performed a study with health care providers of stroke patients in which they provided consultancy to health care providers by trainings and phone calls. ${ }^{37}$ According to their findings, they showed strongly significant difference between the post-test scores of control and experimental groups. $^{37}$

\section{CONCLUSION AND RECOMMENDATIONS}

Conclusively, it was detected that knowledge of all elderly care providers, who were included in the "My elderly and my patient are in safe hands with SODES" project, increased in the end of elderly care and first aid trainings. Experts should provide effective health care services to disadvantaged families and should develop projects.

\section{Funding}

Funding was received from Gaziantep Social Assistance and Solidarity Association of Sahinbey Governor's Office (SODES 2012/1203).

\section{Conflict of interest}

Author declare that there is no conflict of interests regarding the publication of this paper. 


\section{Acknowledgements}

I thank to Proje Owner Deputy Governor Ugur Turan, Proje Partner Prof. Dr. Adnan
Kisa and trainees for their support in our study.

\section{KAYNAKLAR}

1. TUIK. (2013). "İstatistiklerle Yaşlılar". Türkiye İstatistik Kurumu Matbaası, Yayın No: 4158, Ankara. Erişim adresi: http://www.tuik.gov.tr/PrelstatistikTablo.do?istab_id=1588 (Erişim tarihi: 20.03.2020)

2. TUIK. (2013). "İstatistiklerle Yaşlılar" Elderly Statistics. Türkiye İstatistik Kurumu Matbaası, Yayın No: 4365, Ankara. Erişim adresi: http://www.tuik.gov.tr/IcerikGetir. do?istab_id=265 (Erișim tarihi: 20.03.2020).

3. TUIK. (2019). "İstatistiklerle Yaşlılar". Elderly Statistics. Türkiye İstatistik Kurumu Matbaası, Ankara. Erişim adresi: http://www.tuik.gov.tr/PrelstatistikTablo.do?istab_id=1588 (Erișim tarihi: 20.03.2020)

4. General Directorate of Social Sectors and Coordination. (2007). "Türkiye'de Yaşlıların Durumu ve Yaşlanma Ulusal Eylem Planı”. Devlet Planlama Teşkilatı, Ankara. Erişim adresi: http://www.ekutup.dpt.gov.tr/nufus/yaslilik/eylem pla.pdf (Erişim tarihi: 21.03.2020).

5. Caprara, G.V, Caprara, M. and Steca, P. (2003). "Personality's Correlates of Adult Development and Aging”. European Psychologist, 8 (3), 131-147.

6. Efklides, A, Kalaitzidou, M. and Chankin, G. (2003). "Subjective Quality of Life in Old Age in Greece: The Effect of Demographic Factors, Emotional State and Adaptation To Aging”. European Psychologist, 8 (3), 178191.

7. Tanji, H, Ootsuki, M, Matsui, T, Maruyama, M, Nemoto, M, Tomita, N, Seki, T, Iwasaki, K, Arai, H. and Sasaki, H. (2005). "Dementia Care- Givers' Burdens and Use of Public Services." Geriatrics and Gerontology International, 5 (2), 94-98.

8. Roy, R. (2006). "Chronic Pain and Family: A Clinical Perspective.” New York: Springer

9. Kneipp, M.S, Castleman, J.B. and Gailor, N. (2004). "Informal Caregiving Bur-Den: An Overlooked Aspect of The Lives and Health of Women Transitioning From Welfare To Employment?" Public Health Nursing, 21 (1), 24-31.

10. Unalan, P.C, Uzuner, A. ve Cifcili, S. (2009). "Bakıcıların Sesi; Yaşlılar ve Bakıcılık Hakkındaki Algı ve Tutumları". Turkish Journal of Geriatrics, 12 (1), 18-24.

11. Oztop, H, Sener, A. ve Guven, S. (2008). "Evde Bakımın Yașlı ve Aile Açısından Olumlu ve Olumsuz Yönleri”. Yaşlı Sorunları Araştırma Dergisi, 1, 39-49.

12. Erdil, F. (2009). "Yaşlanan Toplum ve Yaşlının Evde Bakımı." Erişim adresi: http://www.ekutuphane.teb.org. tr/pdf/tebakademi/geriatri_2009/23.pdf (Erișim tarihi: 21.03.2020)

13. Talkington, S. (1995). "Ethical Issues in Home Care". HEC Forum, 7, 290-295.

14. Dogan, O. (2001). "Şizofreni Hastalarının Evde Bakımı". Anadolu Psikiyatri Dergisi, 2, 41-46.

15. Erdil, F. ve Bayraktar, N. (2004). "Cerrahi Hastasının Evde Bakımı". Sağlık ve Toplum Dergisi, 14, 3-8.
16. Akdemir, N. (2000). "Geriatri. Yaşlılarımızın Bakım Sorunları İvedilikle Çözümlenmelidir”. Türk Geriatri Dergisi, 3 (4), 169

17. Da Roit, B. (2012). "The Netherlands: The Struggle between Universalism and Cost Containment". Health and Social Care in the Community, 20 (3), 228-237.

18. Szebehely, M. and Trydegård, G.B. (2012). "Home Care for Older People in Sweden: A Universal Model in Transition". Health and Social Care in the Community, 20 (3), 300-309.

19. Osterle, A. and Bauer, G. (2012). "Home Care in Austria The Interplay of Family Orientation, Cash-For-Care and Migrant Care". Health and Social Care in the Community, 20 (3), 265-273

20. Akdemir, N, Bostanoglu, H, Yurtsever, S, Kutlutürkan, S, Kapucu, S. ve Canlı Özer, Z. (2011). "Yatağa Bağıml Hastaların Evde Yaşadıkları Sağlık Sorunlarına Yönelik Evde Bakım Hizmet Gereksinimleri”. Dicle Tıp Dergisi, 38, 57-65.

21. Williams, A.M, Forbes, D.A, Mitchell, J, Essar, M. and Corbett, B. (2003). "The Influence of Income on Experience of Informal Caregiving: Policy Implications". Health Care for Women International, 24 (4), 280-291.

22. Kalınkara, V. (2008). Türkiye'de Yaşlı Nüfusun Dağılım Araştırması. Erişim adresi: http://www.radikal. com.tr/haber .php?haberno=208832 (Erişim tarihi: 21.03.2020).

23. Karadeniz, O. (2011). "Türkiye'de Atipik Çalışan Kadınlar ve Yaygın Sosyal Güvencesizlik". Calışma ve Toplum Ekonomi ve Hukuku Dergisi, 2, 83-127.

24. Akbıyık, N. (2013). "Ev Hizmetlerinde Çalışma: Malatya'd Bir Alan Araştırması". Yönetim ve Ekonomi Araştırmaları Dergisi, 21, 207-240.

25. Kaska, S. (2005). "Ev İçi Hizmetlerin Küreselleșmesi ve Türkiye'deki Göçmen Kadınlar”. Tes-İs Sendikası Dergisi, $49-54$

26. Etiler, N. ve Lordoglu, K. (2010). "Göçmenlerin Sağlık Sorunları: Bir Alan Araştırması." Sosyal Haklar Ulusa Sempozyumu, Denizli.

27. Karaca, N.G. ve Kocabas, F. (2009). "Ev Hizmetlerinde Çalışanların Karşılaştıkları Sorunların Türkiye Açısından Değerlendirilmesi”. Kamu-İs İs Hukuku ve İktisat Dergisi, 10 (4), 161-176.

28. TUIK. (2015). “Adrese Dayalı Nüfus Kayıt Sistemi”. Erișim adresi: http://www.tuik.gov.tr/Veri Tabanlari.do? ust_id=109\&vt_id=28 (Erișim tarihi: 21.03.2020).

29. Durgun, B. ve Tumerdem, Y. (1999). "Kentleşme ve Yaşlılara Sunulan Hizmetler". Geriatri, 2 (3), 115-120.

30. Toksoz, G. ve Erdogdu, S. (2013). "Türkiye'de Ev İşçileri”. Ankara: Uluslararası Calısma Ofisi-International Labor Office-ILO.

31. Genc, Y. and Barıs, I.A. (2015). "Contemporary Approach In Elderly Care: Strengthening The Home Care Services Instead of Institutional Care”. ASOS Journal, 3 (10), 36-57. 
32. Cingil, D, Gozum, S. ve Bodur, S. (2015). "Bağıml Yaşlısına Bakım Veren Aile Üyelerine Sunuş Yolu İle Verilen Eğitimin Bakım Verme Yeterliliği ve Yaşı Bakımı Bilgi Düzeyine Etkisi”. Anadolu Hemşirelik ve Sağlık Bilimleri Dergisi, 18 (4), 259-267.

33. Berg-Weger, B. and Tebb, S.S. (2003-2004). "Conservations With Researchers About Family Caregiving: Trends and Future Directions". Generations, 27 (4), 9-16.

34. Nicolaides-Bouman, A, Van Rossum, E, Habets, $H$, Kempen, G. I. and Knipschild, P. (2007). "Home Visiting Programme for Older People With Health Problems: Process Evaluation". Journal of Advanced Nursing, 58 (5), 425-435.

35. Bodur, S. ve Cingil, D. (2006). "Bağımlı Yaşlıların Aile İçi Bakıcılarının Bakımla İlgili Tutumları ve Eğitimle İlișkisi””. Selçuk Üniversitesi Tıp Dergisi, 22 (4), 149-157.

36. Magnusson, L. and Hanson, E. (2005). "Supporting Frail Older People and Their Family Carers at Home Using Information and Communication Technology: Cost Analysis". Journal of Advanced Nursing, 51 (6), 645-657.

37. Temizer, H. and Gozum, S. (2012). "Impact of Nursing Care Initiatives on The Knowledge Level and Perception of Caregiving Difficulties of Family Members Providing Home Care To Stroke Patients". HealthMED, 6 (8), 2681-2688.

38. Dramalı, A, Demir, F. ve Yavuz, M. (1998). "Evde Kronik Hastaya Bakım Veren Hasta Yakınlarının Karşılaştıkları Sorunlar”. I. Ulusal Evde Bakım Kongresi, İstanbul.

39. Altun, I. (1998). "Hasta Yakınlarının Bakım Verme Rolünde Zorlanma Durumları". I. Ulusal Evde Bakım Kongresi, İstanbul.

40. Aslam Arain, M, Graham, L, Ahmad, A. and Cole, M. (2020). "Pilot Implementation of Elder-Friendly Care Practices in Acute Care Setting: A Mixed Methods Study". BMC Health Services Research, 20, 2-14. 